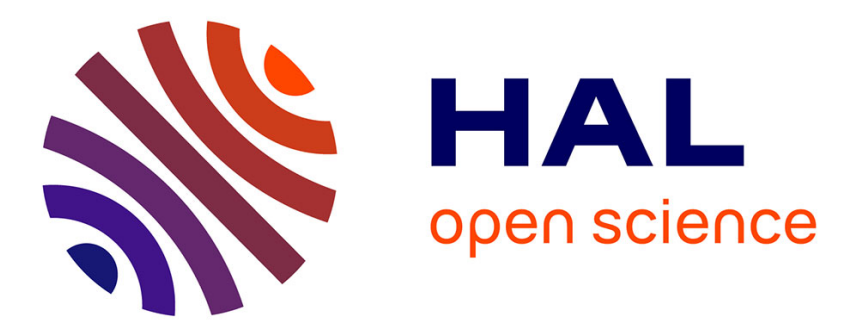

\title{
Protected Areas and Overuse in the Context of Socio-Natural Changes: An Interdisciplinary French Case Study
}

Cécilia Claeys, Carole Barthelemy, Thierry Tatoni, Patrick Bonhomme

\section{To cite this version:}

Cécilia Claeys, Carole Barthelemy, Thierry Tatoni, Patrick Bonhomme. Protected Areas and Overuse in the Context of Socio-Natural Changes: An Interdisciplinary French Case Study. International Review of Social Research, 2011. hal-01756438

\section{HAL Id: hal-01756438 \\ https://hal.science/hal-01756438}

Submitted on 5 Apr 2018

HAL is a multi-disciplinary open access archive for the deposit and dissemination of scientific research documents, whether they are published or not. The documents may come from teaching and research institutions in France or abroad, or from public or private research centers.
L'archive ouverte pluridisciplinaire HAL, est destinée au dépôt et à la diffusion de documents scientifiques de niveau recherche, publiés ou non, émanant des établissements d'enseignement et de recherche français ou étrangers, des laboratoires publics ou privés. 


\title{
Protected Areas and Overuse in the Context of Socio-Natural Changes: An Interdisciplinary French Case Study
}

\author{
Cécilia CLAEYS \\ Aix-Marseille University - UMR Espace \\ Carole BARTHELEMY \\ Aix-Marseille University - LPED \\ Thierry TATONI \\ Aix-Marseille University - IMEP \\ Patrick BONHOMME \\ Aix-Marseille University - COM
}

\begin{abstract}
This article provides an interdisciplinary analysis of the notion of overuse in natural areas. Based on the case of the French Calanques massif (located along the Mediterranean coast between Marseilles and Cassis), sociology and biology combine their analyses to examine the social processes behind the increasingly widespread use of natural areas and the ecological consequences thereof. The data are comprised of interdisciplinary research based on eighty semi-structured interviews conducted on-site and 330 telephone survey questionnaires. We critically analyse of the notion of overuse and underscore the socioeconomic, cultural and ideological weight it carries in the context of socio-natural change; this calls into question the relevance of the ancient nature/culture dichotomy. Drawing on theoretical tools from environmental sociology, this article also provides some perspectives for natural area managers.
\end{abstract}

Keywords: nature-society interactions, Mediterranean ecosystems, sociology, ecology interdisciplinarity, overuse, Calanques.

\section{Introduction}

In the context of global change affecting natural resources, the impact of human activity on such resources is central to environmental rhetoric.

e-mail: cecilia.claeys@univmed.fr Cecilia Claeys is the corresponding author. She is assistant professor of sociology, focusing her researches on environmental conflicts, environmental democracy and risk management. Carole Barthélémy is assistant professor of sociology. Her main research fields are urban biodiversity and nature management. Thierry Tatoni is professor of ecology. He works on biodiversity dynamics and ecological vulnerability. Patrick Bonhomme is engineer in Oceanography, expert in sea environment and professional diver. Acknowledgments: The authors thank Jocelyne Serveau for the English language proofing. We are equally grateful to our anonymous reviewers who provided invaluable constructive feedback and also Lidwine Pecheux and Bertrand Cousin of the Gip-Calanques for their assistance with map design. The article is based on an interdisciplinary research programme funded by the French Ministry of Ecology: FHUVEL - Caractérisation de la fréquentation littorale et détermination d'indicateurs de vulnérabilité écologique pour définir des modes de gestion durable - Cas de la bande littorale du projet de parc national des calanques. Scientific Coordinator: Thierry Tatoni. 
Given the abounding examples which exist, the negative impact of 'mankind' on nature no longer needs to be proven (e.g., the effects of urbanisation, intensive farming, etc.). In this context, the term 'overuse' is used to describe natural areas thought to be endangered and in need of protection from what is considered to be excessive use or disrespect for the surrounding fauna and flora. The notion has emanated essentially from natural area managers whose role consists in part in managing user flows (managing car parks, marking trails, etc.) and in using their abilities to police and control risks (fires, accidents, etc.).

From a scientific perspective, overuse is a transversal concept which can be jointly approached from the social sciences and life sciences. Despite increasing popularity in the environmental field (Roux, Stirzaker, Breen, Lefroy and Cresswell, 2010), interdisciplinarity raises similar epistemological issues in both disciplines due to their respective theoretical backgrounds (Ostrom, 2009). Sociology's Durkheimian legacy and its anthropocentric habit of 'explaining social facts with social facts' is challenged by the need to examine biological processes in order to fully understand environmental issues. Conversely, the biocentric roots of biology are challenged by the need to include mankind in order to fully understand ecosystem dynamics (Jollivet, 1992; Claeys Mekdade, 2003; Jetzkowitz and Brunzel, 2005; Baerlocher and Burger, 2010). The difficulty for sociologists is thus to contribute to defining an interdisciplinary approach without losing critical perspective. Meanwhile, the difficulty for biologists - and even more so for ecologists - is to shed old anthropophobic beliefs rooted in concepts such as climax (Drouin, 1991; Lévêque 2001). In order to avoid such epistemological traps, we shall attempt here to follow the lead of 'win-win ecology', as defined by biologist Michael Rosenzweig (2003), which underscores the possible complementarity between nature and society, on the one hand; and that of sociologist Florian Charvolin (2003), who recommends focusing on socio-natural processes, applying the framework developed by Bruno Latour and Michel Callon to environmental sociology, on the other. Our approach differs from that of Latour and Callon's, however, notably with regard to the role of 'old' social structures; indeed, we believe that the actor network theory tends to minimize the persistent effects of social inequality. It is as such that concepts like ecological inequality and environmental justice help counterbalance the blindness to social class found in Latour and Callon's framework. These analyses indeed work to point up the social inequalities which exist in access to a quality environment and natural areas (Bullard, 1990; Cutter, 1995; Theys, 2007; Deboudt, 2010).

We have opted here to engage in interdisciplinary exchange in our fieldwork and in gathering and analysing data about the social and ecological causes and effects of nature's overuse. Previous interdisciplinary research (Claeys-Mekdade, Géniaux and Luchini, 1999; Gendron, Vaillancourt, Claeys-Mekdade and Rajotte, 1999; Claeys and Sérandour, 2009; Barthélémy and Souchon, 
2009; Bouleau, Argillier, Souchon, Barthélémy and Babut, 2009; Marco, Barthelemy, Dutoit and BertaudièreMontes, 2010) has shown that solid field surveys provide a stronger and richer basis for interdisciplinary exchange than abstract debate which often leads simply to ideological conflict. This position is shared by other researchers such as Jetzkowitz and Brunzel (2005).

It is as such that we shall take a sociological approach which allows us to forge beyond what occasionally seems like an essentially ideological invocation: is overuse actually measured and measurable? What methodological tools are used to do so? Who is advancing the idea and how do affected users perceive it? Conversely, the life sciences can help create measuring tools to understand the impact of use, for example of local flora being tread upon. Between ecological measures on the one hand and ensuring critical distance on the other, can the notion of overuse constitute an example of interdisciplinary crossover between the social sciences and the life sciences in the context of natural area management? Can it provide a textbook example of disciplinary decompartmentalisation for understanding hybrid, socionatural objects (Charvolin, 2003; Claeys-Mekdade, 2003) specific to the environmental field?

To address these questions, we shall look at the Calanques massif situated on the French Mediterranean coast. This massif provides an exemplary case study for how the concept of overuse has been dealt with:

1) Ecological characteristics have earned it the title of being an 'exceptional' site, both in terms of its biodiversity and also due to the specificity of its ecosystems and landscape;

2) Its proximity to Marseilles, the second largest French city, with over 800,000 inhabitants, has made it a peri-urban site;

3) Finally, the massif is currently the focus of a national park project that has created several controversies locally, most of which are related to the issue of use.

The present article thus aims to reflect on potential interdisciplinarity in an area with strong environmental and socio-economic stakes. After presenting the methodology and data, we shall begin with a quick overview of how users progressively appropriated the massif; then we will take an interdisciplinary look at the notion of overuse; finally, we will examine the cross-over between nature and culture and the paradoxes inherent to the principles behind the protection of nature in the context of socio-natural changes.

\section{Data and Methods}

Our research is based on a corpus which combines data from a direct observation survey among managers and stakeholders, a qualitative survey (interviews) among users of the Calanques and a questionnaire survey of inhabitants of the city of Marseilles. These complementary approaches allow us to take into consideration the discourse, habits and expectations of site managers, site users and inhabitants from the neighbouring agglomeration. The methodological 
originality of these studies is that they were directly conceived from an interdisciplinary perspective. As such, the sociological approach was enhanced by contributions from ecology with regard to the choice of zones surveyed and in the wording of interview grids and questionnaires in order to focus the study on zones and objects where ecological factors (endangered endemic species) and sociological factors (the entrance points to the massif closest to the city of Marseilles) converge. Finally, ecology assessed the vulnerability of coastal ecosystems in terms of use and human traffic in these areas.

Our participatory approach is based on regular contact between sociologists, managers and stakeholders during scientific committees and consultation meetings. These opportunities provided a means to study how site management policies are designed and implemented, as well as study the debate over the creation of a national park through direct observation and a participatory approach. The qualitative approach is based on a survey using semi-structured interviews with eighty land- and sea-users in the Calanques. It focuses on three areas characterised by three specific ecological interests: one land and two sea areas.

The chosen land area - the Marseilleveyre massif between the Mont-Rose and Marseilleveyre Calanques - is one of the entry points to the Calanques closest to Marseilles. It is also one of the main Mediterranean hotspots for endemic flora, especially phrygana. Phrygana is a spatially fragmented bushy thermo-Mediterranean sclerophyll plant formation that is confined almost exclusively to the coast of the Marseilles Calanques. It is made up of three 'key' protected plant species: Astragalus tragacantha (Fabaceae), Plantago subulata (Plantaginaceae) and Thymelaea tartonraira (Thymeleaceae), located along a fairly narrow coastal strip (generally 20 to 80 meters from the sea). It adapts remarkably to extreme environmental conditions (e.g. drought, salinity, mainly bedrock) (Rotondi, Rossi, Asunis and Cesaraccio, 2003; Munns and Tester, 2008).

We also analysed two sea areas. The first is a popular diving location called the Farillons. It is of great ecological interest due to the presence of a specific type of coralligenous fauna. The coralligenous wall is known, among other things, for its large invertebrates (gorgonians, bryozoa and sponges). These underwater landscapes have an important function value in the ecological makeup and landscape diversity. The Farillons site has a large array of species and an architecturally impressive sea floor; it is very popular amongst divers. Signs of deterioration were detected as early as 1996 and were blamed on both pollutant releases from the Cortiou outfall which admits treated sewage from the treatment plant for the city of Marseilles and on increased use, including anchoring, fishing, underwater fishing and scuba diving (Harmelin, Sartoretto and Francour, 1996). This type of site is thus particularly vulnerable.

The second sea area is the Sormiou Calanque, famous for yachting and whose sea floor is covered by Posidonia oceanica, a protected sea grass especially vulnerable to anchoring. Posidonia oceanica is a 
species endemic to the Mediterranean region. It is one of the most important ecosystems in the Mediterranean for several reasons, most notably due to the diversity of fauna and flora it contains, for its role in maintaining the coast's sediment balance and for its role as a spawning grounds and nursery for numerous fish and crustaceans (Boudouresque, Mayot and Pergent,
2006). The Sormiou Calanque is the largest Calanque of the entire massif. Prospecting done in 2004 whilst mapping marine biocoenosis for a Natura 2000 project underscored the growing number of anchor marks, particularly starting at $10 \mathrm{~m}$ in depth (Bonhomme et al., 2005); Posidonia sea grass grows only in depths ranging from 1 to 29 metres.

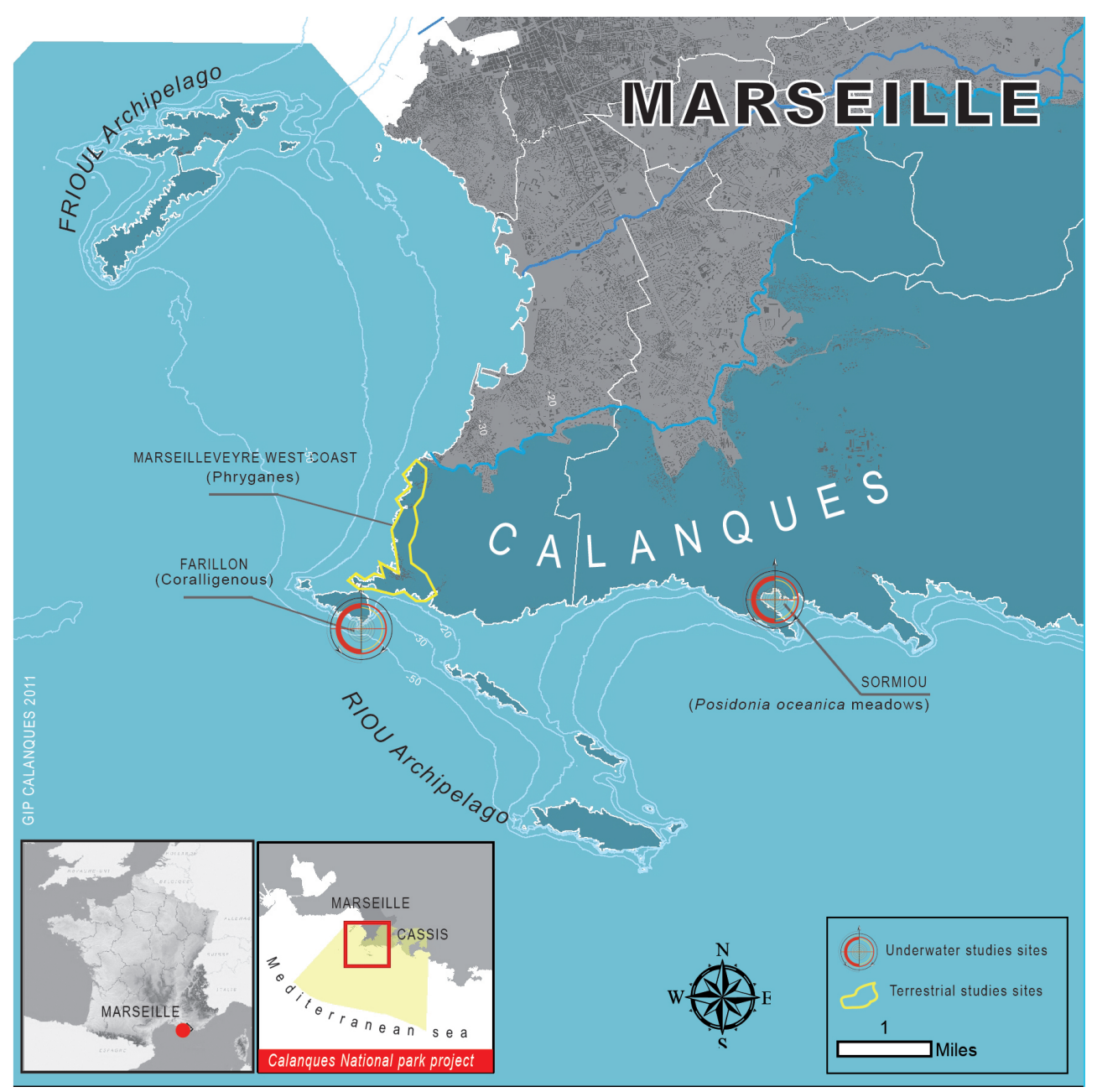

Figure 1. The Calanques of Marseilles areas studied.

Source: GIP-Calanques.

All interviews were conducted onsite, except with scuba divers who use the area only for diving and spend little time outside the water; the latter provided no opportunity to interview them on-site and we therefore 
interviewed them at their dive clubs. To ensure that a variety of uses and users were covered, the land and yachting interviews were conducted at different times of the year (spring, summer and autumn), on different days of the week (weekdays and weekends) and at different times of day (morning, afternoon and evening). The three types of users were asked similar questions about their thoughts on and uses of the Calanques, their awareness of the planned national park and their perception of the area's 'overuse'. Some more specific questions were also targeted at each type of user and their awareness about endemic plants characteristic of the area. This approach allowed us to consult users in context and let them speak about the surrounding nature and their activities while doing so. It further took into consideration all users regardless of where they were from. All interviews were recorded and fully transcribed. They were analysed following sociology's classical content analysis method.

A telephone survey with inhabitants of Marseilles was also conducted. This approach provided a general overview of the relationship between the inhabitants of the nearest and largest city and the Calanques, including both users and non-users of the area. We focused on Marseilles for demographic reasons and because it is a major focus of managers for this same reason. Quota sampling was used (gender, age and profession), gathering 330 questionnaires from people representative of the inhabitants of three districts of Marseilles (south, centre and west). This survey used multiple-choice questions about the same topics as the qualitative survey, notably regarding inhabitants' thoughts and activities about the Calanques and their awareness of the planned national park. The data were analysed using a descriptive statistics approach based on three main actions: frequency distribution, cross-tabulations and chisquare testing.

\section{The Calanques. From Invisible Territory to Overused Territory?}

Located between Marseilles and Cassis, the limestone Calanques massif, from the Provençal 'calanca', meaning 'sharp incline', is a semiarid environment. Until the $19^{\text {th }}$ century, the massif was an aesthetically, socially and economically marginal territory. Difficult to access, there was little to no development in the massif. There were only a few fishing cabins belonging to small-scale fishermen nestled in the crannies of the Calanques. From the 19th century onwards, this territory and its uses began to change substantially according to two antithetical axes characteristic of burgeoning modernity and its critics. One is related to the industrial exploitation of the site and the other to the premise of protecting nature. As such, the implantation of industrial lime-burning kilns was accompanied by the creation of lead, lye and acid producing factories. Downwind from the city of Marseilles, smokestacks ran along the edge of the massif and released their fumes full of heavy metals. And yet the flourishing activity of these industries was not long lived (Goiffon and Consalès, 2005); even before their decline, other activities and eyes were looking to 
the slopes of Marseilles' massif and it was taken almost without a transition period from industrial production to protection for recreational purposes. As part of the French Alpine Club (C.A.F.) movement and with the application of the first legal texts explicitly in favour of protecting the environment, notably the 4 April 1882 Restoration of Mountain Lands law, the Calanques massif was redefined as an important natural area. As such, through the Marseilles section of the C.A.F. and its local renegade, the Association of Marseilles Hikers, the urban bourgeoisie quickly found the Calanques massif well suited for the projection of a new aesthetic vision promoted at the national and European level by an intellectual elite inspired by naturalist and public health discourse which advocated fresh air and sport (Massena-Gourc, 1994; van Koppen and Markham, 2007). Following a classic process known as the first and second green waves (Spaargaren and Mol, 1992), continuity with the activism of these local elites - the pioneers of nature protection - was pursued by the intellectual middle classes and their contemporary environmental concerns.

A similar situation occurred among sea users. Scuba-diving equipment, which had been restricted to professional and military use, underwent a complete technological revolution in the $1950 \mathrm{~s}$, thanks notably to the impetus of JeanJacques Cousteau. The French Diving Federation had 2,376 members in 1955; in 2004, there were 150,000 members, representing 47 per cent of all French divers (for details: http://www.ffessm. fr/). The history of contemporary French diving is intricately tied to Marseilles, where the Beuchat Company, specialized in diving equipment, was founded in 1934 and where Comex, the world leader in manned and robotic underwater engineering, technology and interventions, was founded in 1961. In addition, Marseilles was one of Jean-Jacques Cousteau's favourite bases and many members of his dive team were natives of the city. The numerous old and modern-day wrecks, the limestone sea arches and dropoffs and, more recently, discovery of a prehistoric cave by diver Henri Cosquer have made the Marseilles Calanques and waterfront a worldrenowned dive site.

Yachting is also a major sport around Marseilles. The legend of the city's founding recounts that in 600 BC, Gyptis, Princess of the inlanddwelling Ligurians, chose Protis as her husband, the chief sailor from Phocaea who had come to conquer new colonies. Marseilles was an extremely prosperous port city in the colonial period and it is still very tied to the sea. According to iconographic resources, the first pleasure boats - meaning devoted strictly to recreational use appeared in the 18th century (Poilroux, 1982). Small crafts shifted slowly from business purposes to recreational use and at some stages were multi-purpose, used for fishing in the morning and for family outings in the afternoon. Some cabin dwellers continue to perpetuate this tradition today. The first official regatta was inaugurated by the Mayor of Marseilles in 1846 and the tradition still lives on (Poilroux, 1982). Like walking and diving, yachting has since become increasingly popular. There are currently four million recreational boaters in France (for details: www. developpement-durable.gouv).

Like many other natural areas, the 
increased amount of free time over the past few years (Dumazedier, 1974; Corbin, 1995; Roberts, 2006) has meant that the Calanques have become a showcase for the rise of outdoor leisure activities and a show ring for the diversification and intensification of such activities. Conceptualised by Dunlap et al. (2000) as the rise of a New Ecological Paradigm and by Wilson (1993) and van der Born et al. (2006) as the spread of biophilia, the relative generalisation of biocentric environmental values has resulted in a widespread desire for nature in general and for the Calanques in particular as an escape from city life. In this context, people are aware of the project to create a national park and most of the people we met during the qualitative and quantitative surveys accepted the idea (seventy-two per cent of inhabitants contacted and sixty-six per cent of users interviewed).

When we moved beyond the basic idea and began to discuss the actual consequences of such a project, however, users became more reserved and even expressed their opposition to the project. The main fear was that a national park would lead to an increase in regulations and bans, including restricted access. Apprehension over restricted access to national parks has been widely discussed in research by authors such as Bauer, Wallner and Hunziker (2010) with regard to Switzerland where they highlighted a cultural effect among French speakers who tend to be less open to restrictions and bans than other groups in the population. Indeed, during the consultation process around the national park project in the Calanques, restrictions and bans were the most controversial subject. Representatives for the different types of users all argued that their activity had little impact on the ecosystem and they tended to openly challenge the opinions of managers, pointing to a lack of scientific research on the topic.

Users of the Calanques are particularly hard to quantify, however, since the number of entry points to the massif and their geographical distribution, the diversity of uses, but also the diversity of institutions which manage the different areas of the site and the resulting lack of coordinated policy to monitor use encourage ideological speculation rather than founded knowledge about and an objective quantification of use. Disparate data exist, but the diversity of observation protocols from which they come limit the ability to compare across space and time. Such heterogeneous sources make it possible to identify the diverse ways the Calanques are used and to suggest an overall hierarchy, yet they do not allow for a solid general quantification and even less so for a quantification of how use has evolved over time. The quantification of information and awareness-raising campaigns held during the summer season by 'green patrols' do provide some idea (Figure 2); however the annual variation observed is due to numerous uncontrolled variables such as the weather, number of days the massif is closed due to fire risks and, above all, the number of patrollers working and the variety of jobs assigned to them.

Our questionnaire allowed us to assess the portion of inhabitants in Marseilles that use the Calanques. While forty per cent of our sample 
described the Calanques as their favourite natural area in the region, nineteen per cent had never been to the Calanques; sixty-three per cent visit the Calanques occasionally and eighteen per cent go regularly. Although wellknown and respected, the Calanques remain an occasional destination for most inhabitants. There is, however, a geographical effect since inhabitants of the nearest neighbouring town tend to visit the Calanques somewhat more regularly (twenty-nine per cent of inhabitants).

And yet, this information alone is not sufficient to address the issue of defining levels of overuse. Indeed, what defines a situation of overuse? Based on what criteria? But also according to whom?

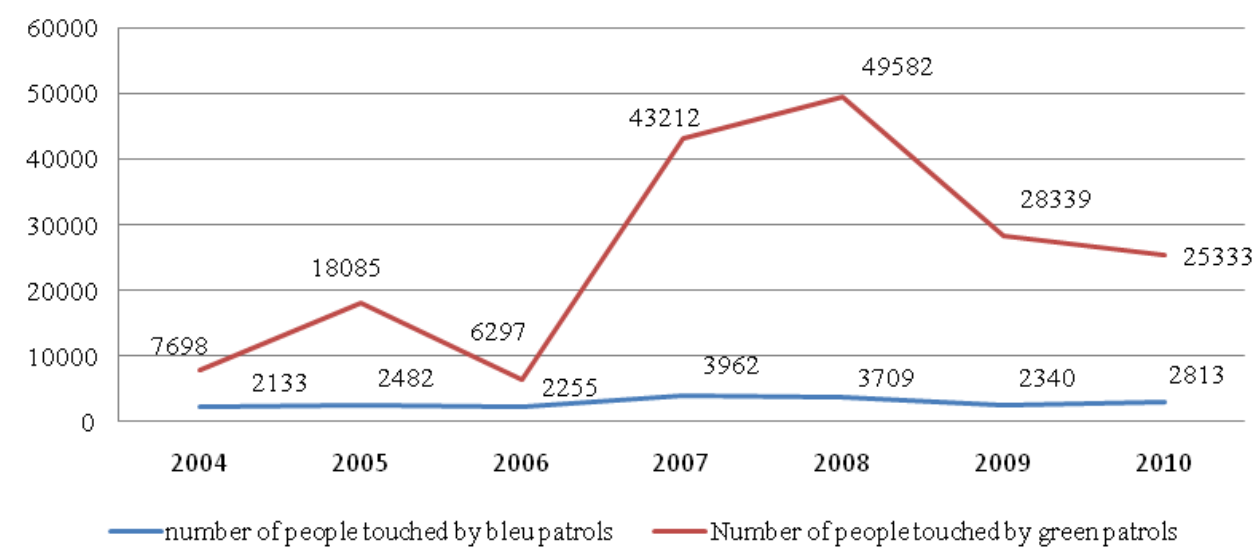

Figure 2. Evolution in the number of people touched by green and blue patrols since 2004 Source: Authors' computation based on GipCalanques (2010).

\section{Overuse. Ecological Consequences and Social Stakes}

Beyond their heterogeneity, the different attempts to observe use have nonetheless identified walking (from hiking to leisurely strolls) and swimming as the two most prominent activities in the Calanques. While the former is practised year round, the latter remains tied to the summer season; several other activities are also practised on-site such as running, cycling (especially mountain biking), rock climbing, fishing, sailing, hunting, paragliding, scuba diving, kayaking, rowing and jet-skiing, to name a few (Massena-Gourc, 1994, GipCalanques, 2010).
As mentioned above, hikers and climbers were the first to voice their demands for protection of the Calanques site; however the breadth of these activities, especially hiking which now spans from multi-day trekking to digestive strolling also begs the question of how these pioneering activities have impacted nature. Indeed, paradoxically, hiking and climbing are often thought of as environmentally friendly activities and yet they clearly have an impact on natural areas: treading on plant cover, the erosion of paths and even illegal behaviour such as removing fauna and flora or fires started by cigarette butts and campfires, as well as the deterioration caused by motor vehicles 
(cars, motorbikes, off-road vehicles, etc.) and their disorderly parking in coastal areas directly next to roads and trails (McKinney, 2002; Pauchard, Aguayo, Peña and Urrutia, 2006), particularly harmful to the phrygana which is located along a coastal strip that is directly adjacent to urban zones. These zones are the starting point for most coastal human activity: e.g. walks, fishing and swimming spots, roads and car parks. And yet, the phrygana plant formations are fragile, with very low natural recruitment rates, and are very sensitive to climatic variation, which can lead to major germination loss. Like many continental, coastal and insular plant formations, the phrygana is spatially dispersed and limited, with very few areas of abundance and very disturbed population trends. It has to contend with organic pollutants (surface active agents and hydrocarbons) in the urban effluents of Marseille which lead to major necrosis, as well as the complete desiccation of some plants, the harmful effects of inorganic pollutants in the ground from the former industrial activities and the repeated effect of being trodden on, particularly during the reproduction period (May to June).

Similarly, yachting - and sailing in particular - is seen as an environmentally friendly activity and yet anchoring can damage the fragile Posidonia oceanica meadows (Leriche, Pasqualini, Boudouresque, Bernard, Bonhomme, Clabaut and Denis, 2006). Scuba divers, too, whose sport aims to observe underwater landscapes, may also disturb sea life and damage coralligenous communities with their fins or by directly touching the flora.

In this context, the focus on overuse has been heterogeneous and has varied greatly from one social stakeholder to another. Overuse is a primary concern for the different site managers and for those who support the creation of a national park. As such, it was at the centre of heated debate in 2010 during consultation over the park's creation. Whilst local elected officials involved in the consultation, well aware of their electorate's interests, tried to defend the consensual image of the Calanques massif as an area of freedom, managers with scientific research to back-up their claims quickly advocated restricting use. The representatives of different user groups tended to promote the environmentally friendly nature of their respective activities, calling unfair and abusive all proposals to limit their activities; they did not hesitate to initiate petitions and street demonstrations alongside the consultation to make their demands heard. In this context, the positions of the most radical naturalists which contributed to the initial national park project and who dreamed of a massif mainly cut-off from users are now nuanced by a new generation of scientists and managers who would like to find an approach which is more inclusive of social demand. It is in this spirit that the national park initiative chose 'Sharing Nature' as its slogan. Categorising overuse as a danger could lead to the exclusion of human populations from the territory and might create or accentuate environmental inequality (Wilks, 2008; Larrère, 2009; Deboubt, 2010). Further, the potentially overused area does not cover the entire massif since its particularly steep nature means that access is difficult if not impossible to a 
large part of the area.

Given this, and without waiting for the creation of a national park, managers have focused their attention on information campaigns about the fragility of ecosystems alongside strategies to channel and redirect the public towards areas with a less vulnerable ecosystem.

The overuse deemed worrisome by scientists and managers is perceived very differently by users. During our on-site research, only a minority of those interviewed believed that the Calanques were overused. As such, of the eighty people interviewed, fifty per cent did not believe that the Calanques were overused; thirty-three per cent believed that use was concentrated in time and space; and, finally, only eleven per cent believed that the site was overused. Even amongst the most critical individuals, their reasoning tended to advocate a certain form of egalitarian tolerance or strategies for spatiotemporal isolation by avoiding some seasons or the busiest areas. One user from Marseilles, for example, who admitted to being bothered by the number of people, added: 'Yes, it's crowded. But one can't forbid people from coming to see such a beautiful place'. This walker described his avoidance strategy: 'There are plenty of people. But the secret is to walk 15 minutes more than the others and it's quiet again!'. Another person joked about it: 'Well, let's forbid access to the Calanques to everybody but me!'.

Finally, criticism of modern society as the cause of overuse and its corollary, idealisation of the past, are recurrent in environmental discourse and they lead us to question the novelty of the phenomenon. The few existing historical retrospective studies are extremely revealing in this respect. As the historical and ethnographic research of C. Gontier (1991) shows, the overuse of some Calanques, especially those first accessible by water taxi and shuttle, was already decried by the most critical protagonists at the very beginning of $20^{\text {th }}$ century.

While we cannot yet quantify users, it is nonetheless obvious that their diversity encourages conflicts of use and representation. Each person quenches their desire for nature according to their class habitus, but also to generational habitus, and the ambivalence between what is ordinary, familiar and remarkable unites as much as it divides site users who symbolically and/or physically appropriate the area for themselves. In this respect, the definition of the Calanques as an area of freedom is a leitmotif, but its meaning and application take on different forms which are sometimes incompatible and which oppose the individual and the group, what is intellectualised from what is fun, noise and silence, isolation (alone or with a chosen group) and gregariousness, relaxation and physical effort, but also more widely physical versus symbolic appropriation.

Many walkers who express concern for the environment - the heirs to the 19th century hikers - favour erudite contemplation as a means of symbolic appropriation; they challenge any form of physical appropriation of the Calanques, criticising those who disturb nature (e.g., hunting, fishing and picking) and their traditional habitat, the cabin. And yet, just as a deep and lasting divide is drawn between the two main types of site 
users (Massena-Gourc, 1994), the main point that opposes them, contemplating versus disturbing nature, has been attenuated. Indeed, former hunting and fishing cabins have progressively been transformed into holiday homes; others have been built directly for this purpose (Gontier, 1991). 'Cabin parties' - the popular male activity during which the catch from hunting and fishing was consumed - have now become family events. The proportion of food hunted, fished and consumed at cabins has declined and virtually disappeared altogether in favour of store-bought goods easily transported on-site by car, far from the picturesque expeditions of centuries past, in clogs or espadrilles, walking alongside a donkey with a packsaddle.

Slowly other local families joined those who inherited the first cabins and a gentrification process began. Whilst some cabins initially made of scrap materials were turned into small neoProvençal style houses (e.g., Sormiou and Morgiou Calanques), others in the Calanques closer to the city, almost surrounded by the urban environment, were turned into primary residences or holiday homes (La Madrague, Les Goudes and, to a lesser extent, Callelongue). As such, the opposition is no longer between contemplating versus disturbing nature, but rather between being itinerant or sedentary. Itinerant use of the Calanques better lends itself to symbolic appropriation (defining a point of view and activities as the only legitimate ones and implicit or explicit disqualification of other uses), but it also involves some physical appropriation, albeit light but not insignificant, through the landscaping and marking of trails and climbing routes. Conversely, the sedentary lifestyle of a (seasonal or permanent) home is fully part of the legal-or illegal but tolerated-physical appropriation of nature which has in the face of criticism also developed types of symbolic appropriation, drawing on arguments about environmentally friendly cultural heritage. In this respect, and despite their hunting and fishing heritage, cabin dwellers tend to share this new biophilic perspective.

Beyond the diversity of leisure activities, a single activity may take a very different shape and have different meaning for different individuals. Walking, the main land-based activity, is a particularly good example of this. Groups of turbulent youth from working class districts, extended families out for an after-lunch walk, strolling lovers or swingers on the prowl (this activity is mainly limited to a Calanque called Mont-Rose), amateur walkers and experienced hikers all share as well as fight over the entrance points to the massif.

Although particularly exacerbated during the consultation process conducted around the national park project, such conflicts of use and representation should not shadow the social and cultural homogeneity of site users. As such, the most visible conflicts actually involve those most present in public debate but who are in reality demographically quite insignificant (hunters, fishermen and cabin dwellers). Such distortion between political and cultural visibility and demographic weight is due to local, national and international political stakes surrounding these specific activities and the ever-increasing restrictions imposed in the name of 
protecting nature.

Indeed, the survey questionnaire we administered to a sample of Marseilles inhabitants revealed that massif use is strongly tied to high cultural capital, regardless of the district where people live and whether it is near or far from the Calanques (Figure 3).

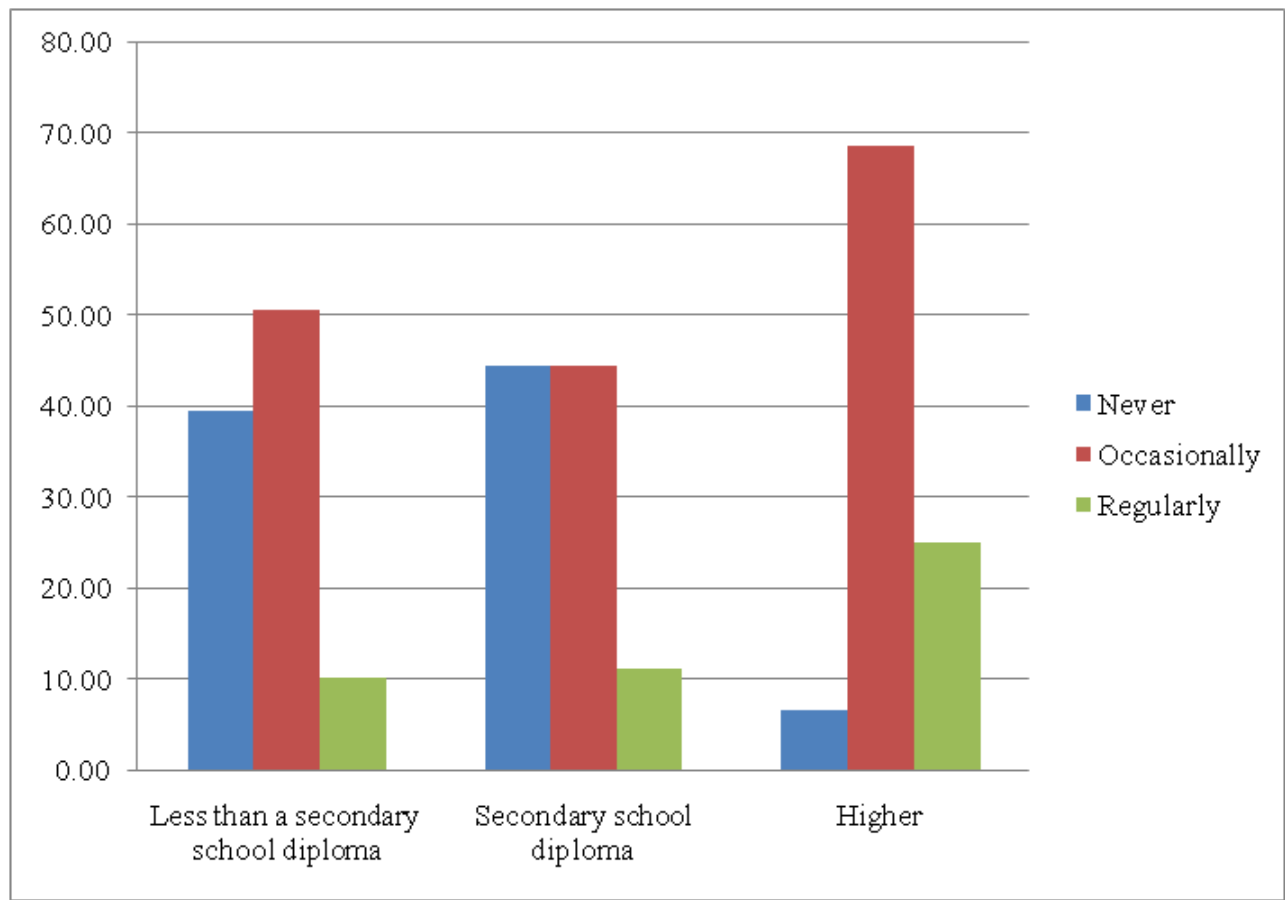

Figure 3. The use of the Calanques by inhabitants of Marseilles depending on their cultural

Source: Our data. capital

The qualitative survey we conducted on-site also corroborated the predominance of individuals with high cultural capital amongst users of the Calanques. As such, whilst some managers tend to use dramatic discourse based on fear of overuse and urban hordes invading the endangered wilderness, some journalists (wee notably the thematic issue of Géo magazine, March 2011) idealise nature without social barriers in which even the poorest Marseilles inhabitants have equal access to this exceptional natural area. And yet the urban districts closest to the Calanques are also amongst the wealthiest in the city of Marseilles whereas the working class districts are the furthest away. As such, use or overuse of the massif reveals that a certain type of aesthetic, sporty and naturalist appropriation of nature is extremely present in the Calanques. Rather than revealing a democratisation of nature-based leisure activities in the sense of 'open to all, tied to urbanisation', use of the Calanques is the result of an increased interest in being in contact with nature and this is something which is not equal throughout the population. 


\section{Remarkable Nature. Consensus and Dissension}

Beyond user conflicts and social inequality in terms of access to the site, inhabitants of Marseilles and massif users all underscored the beauty of the Calanques. In our research questionnaire, ninety-six per cent of the inhabitants of Marseilles questioned found that the Calanques were a remarkable landscape. Such is the originality of Marseilles: there is an incredible natural space within eyesight which, through its physical location and importance for identity, is both an ordinary area which is familiar and common, but also extraordinary in its spectacular and monumental aspects.

Naturalists' and environmentalists' aesthetic reclassification of the Calanques starting in the $19^{\text {th }}$ century was quickly torn between the sublimation of stone and the desire for green space. The Calanques have been described as a natural limestone monument with which climbers are one. The steep cliffs which plunge into the azure Mediterranean are now internationally renowned and relished by the best climbers as well as by rock climbing schools. Within our corpus of interviews, the words used to describe the Calanques were distributed as follows: thirty-three per cent of references used qualifiers related to 'magnificent'; thirty per cent to 'wild'; twenty-seven per cent to 'natural', and twenty-five per cent to 'beauty'. For instance, this user explained: 'What I really like is the mineral aspect. It's so different and so quiet'. Another one added that 'the wildness of the rock face is simply majestic'.
Yet at the same time, the massif's semiarid landscape tends to be associated with an abnormal lack of vegetation which needs to be rectified. As such, recurrent (re)afforestation activities have been undertaken since the end of the $19^{\text {th }}$ century (MassenaGourc, 1994) by institutional stakeholders, particularly the ONF (French National Forest Office), but also user associations and the Boy Scouts of France. The effects of such voluntary (re)afforestation and, even more so, the decline and disappearance of lime-burning kilns, charcoal kilns and urban firewood collection have contributed to the revegetation of the Calanques massif; paradoxically, this has happened alongside media coverage and rising environmental discourse about the endangering of nature's green spaces due to recurrent forest fires (Massena-Gourc, 1994; Chalvet 2011).

In addition to organised (re) afforestation policies, the desire for greenery has also taken the form of isolated individual initiatives which have nonetheless visibly impacted the ecosystem. The desire for greenery and revegetation activities, as well as the related (re)afforestation, can be explained by a cosmogony of nature largely imported from the north of France and Europe more widely. Indeed, dominant social representations of nature at the national and international levels promote the image of green landscapes and high forests (Eizner, 1994; Claeys-Mekdade and Jacqué, 2000). The representations of local users and decision-makers are as such torn between their empirical experience with stone-based nature and ideals of green nature revisited through 
the current trend of Mediterranean gardens happily liberated from botanical taxonomies in favour of exotic species from semiarid or subtropical environments (Claeys, 2010).

The planting of such exotic plant species and attempts to green and reforest the environment pose different ecological problems and put resistant cultivated species in competition with vulnerable endemic species (Gritti, Smith and Sykes, 2006; Affre, Suehs, Charpentier, Vilà, Brundu, Lambdon, Traveset and Hulme, 2010). The most remarkable continental ecosystems in the Calanques are located in areas largely dominated by stone: from the lapis balconies along the crests to the coastal rocks to the talus deposits. It is indeed in these highly constrained areas that we can see nature which is particularly adapted to the drastic environmental conditions and which bestows its ecological originality on the entire Calanques massif; they also contain most of the endangered species and largely contribute to the area's vast biodiversity (Dumas, Affre and Tatoni, 2007; Crouzet, Pavon and Michaud, 2009). In this context, attempts to modify the plant cover and especially to 'green' the environment have led to the trivialisation of specific suites, loss of ecological uniqueness (acquired over a very long period, through rare and complex evolutionary processes) and, ultimately, have introduced a non-negligible risk to endemic species (Médail and Verlaque, 1997; Blondel and Médail, 2009; Amm, Boissy, Brest, Di Liello, Dumas, Affre, Baumel, Roche, Tatoni, Torre, Delauge and Patrick, 2009).

Regarding sea users, their perception of flora is related to their activity. Thus, scuba divers tend to focus more on fish than on flora. They appreciate dive sites for the size and the quantity of fish they expect to see. The Mediterranean grouper is particularly sought-after as a spectacular endemic species and divers also underscore the increasing presence of exotic species such as barracuda; their familiarity with aquatic flora, however, is more general and vague. They are not familiar with the word 'coralligenous'. Aquatic flora is seen as part of the seascape, like the cliffs and wrecks. Such a weak perception of the flora in general and of coralligenous communities in particular lead them to underestimate the environmental impact that diving can have. Boaters, on the other hand, are more aware of flora, especially Posidonia oceanica. Fifty eight per cent of them have heard about it, either through the local and national media or via information campaigns lead by environmental associations and institutions which target them specifically. In this case, biocentrism and anthropocentrism share a common interest: indeed, for safety reasons, most of the boaters interviewed preferred anchoring in sandy areas since their anchors do not hold well in sea grass.

There is no correlation, however, between believing the natural environment is polluted and knowledge about local fauna and flora. It is actually quite the opposite: yachters, who were best informed about local species, talked about the improving marine environment whilst land users, the least informed, were the most pessimistic. This discrepancy is interesting since it is likely due to greater communication about Posidonia sea grass, emblematic of the marine environment, whilst very 
little is known about phrygana. It is also related to the need to understand the marine environment when involved in a marine activity, whereas walking requires only a contemplative relationship with nature.

The general public's complete ignorance of phrygana raises questions about the delay between the scientific construction of an environmental problem and its dissemination to users. An ecological interpretation focused on protecting a plant species does not encourage the species to be taken into account in primarily aesthetic interpretations. Users are often asked to know about endangered species, but managers should also make an effort to provide a more comprehensive reading of nature in which phrygana would occupy a key place. The divide between comprehensive and specific approaches to nature is still very real.

\section{Conclusions}

The Calanques Massif case shows that practices meant to be environmentally friendly can actually have an unwittingly destructive effect on the ecosystem when they become generalised. The 'over'-use of natural areas is a perfect example of this and it is increasingly preoccupying naturalists now caught in the trap of their own urbanophobic exhortations (Claeys and Sirost, 2010). They were indeed the first to decry the ravages of modernity and the damage caused by urbanity, boasting the beneficial virtues of nature (Cadoret, 1985, van Koppen and Markham, 2007); and yet although this vision of nature is now the ideological reference, it has been exposed to forms of re-appropriation free from naturalist taxonomies (typically endemic versus exotic species, visible aridity versus remarkable biodiversity), which have produced increasing social demand for 'landscaped wilderness' (Kalaora, 2001; Cordell et al. 2003).

Such demand for 'landscaped wilderness', the ultimate insult to the most purist naturalists, is nonetheless practically inevitable for several reasons. Firstly, there are currently few places on earth free from some form of anthropic influence (Swyngedow, 2006). Secondly, the closing of an environment to the public in order to protect it goes against increasing concern about limiting environmental inequality (Wilks, 2008). Thirdly, the very concept of managing the environment generates a paradoxical situation in which the manager, by intervening in the environment for its protection, actually becomes nature's gardener (Claeys, 2010).

The interdisciplinary approach taken here is an attempt to move beyond the environmental order which rests on a paradoxical representation in which mankind is both a destroyer and protector of natural areas. In order to move beyond this dichotomy, dialogue between disciplines is a first step in deconstructing the notion of overuse and its impact on nature. While the social sciences frequently rely on a quantitative approach, this provides only partial results; a qualitative approach can better reveal the diversity of viewpoints towards nature activities. Research in ecology is also limited in scale to the plant species studied and does not produce quantitatively proven measures. Such deadlock is evidence of the need to 
challenge the very notion of overuse: is it a relevant concept in working towards the concerted management of nature or is it ultimately too limited to make sense of accepted or acceptable management practices? It seems best to move away from an analysis based on mankind's impact on nature and to try to understand the two as interactions which may sometimes be harmful but which are also sometimes compatible. Ecologists could thus focus on measuring the degree of resilience and compatibility, whilst sociologists could work to find a common basis for potential understanding amidst the diversity of practices. As such, protecting the environment could be understood as a social and physical reality under construction, where the obsolete barrier between natural and artificial could leave way for an 'accepted' socio-natural system.

\section{References}

Affre, L., C. M. Suehs, S. Charpentier, M. Vilà, G. Brundu, P. Lambdon, A. Traveset and P. E. Hulme (2010) 'Consistency on the habitat degree of invasion for three invasive plant species across Mediterranean islands'. Biological Invasions, 12 (8): 2537-2548.

Amm, A., M. L. Boissy, S. Brest, M. Di Liello, P. J. Dumas, L. Affre, A. Baumel, P. Roche, T. Tatoni, F. Torre, J. Delauge and V. Patrick (2009) Vulnerability of Mediterranean coastal phryganas. Congrès International de la SISV et FIP: Biodiversity Hotspots in the Mediterranean Area. Cagliari, Italy. Baerlocher, B. and P. Burger (2010) 'Ecological Regimes: Towards a Conceptual Integration of Biophysical Environment into Social Theory' In Gross, M. and H. Heinrichs (eds.) Environmental Sociology: European Perspectives and Interdisciplinary Challenges, pp. 79-93. Dordrecht: Springer.

Bauer, N., A. Wallner and M. Hunziker (2008) 'The change of European Landscapes: Human - nature relationships, public attitudes towards rewilding, and the implications for landscape management in Switzerland'. Journal of Environmental Management, 90 (9): 2910-2920.

Barthélémy, C. and Y. Souchon (2009). 'La restauration écologique du Rhône sous le double regard du sociologue et de l'écologue'. Natures Sciences Sociétés, 17: 113-121.

Blondel, J. and F. Médail (2009) 'Biodiversity and Conservation' In Woodward, J. C. (ed.) The Physical Geography of the Mediterranean, pp. 615-650. Oxford: Oxford University Press.

Bonhomme, P., A. Ganteaume, G. Bellan, G. Cadiou, E. Emery, P. Clabaut, G. Bernard, G. Hervé, M. Bourcier and C. F. Boudouresque (2005). Etude et cartographie des biocénoses marines des calanques de Marseille à Cassis, y compris l'archipel de Riou. Phase 3 : Rapport final. Contrat GIS PosidonieIFREMER-COM/GIP des Calanques. 1-156.

Boudouresque, C. F., N. Mayot and G. Pergent (2006) 'The outstanding traits of the functioning of the Posidonia oceanica seagrass ecosystem'. Biol. Mar. Medit., 13 (4): 109-113. 
Bouleau, G., C. Argillier, Y. Souchon, C. Barthélémy and M. Babut (2009). 'How bioindication reveals social changes in water management, the case of lakes and rivers in France'. Ecological Indicators, 9 (6): 1198-1205.

Bullard, R.D. (1990) Dumping in Dixie: Race, Class and Environmental Quality (3rd ed.). Boulder, CO: Westview Press.

Cadoret, A. (1985) (ed.) Protection de la nature. Histoire et idéologie: de la nature à l'environnement. Paris : L'Harmattan.

Callon, M., P. Lascoumes and Y. Barthe (2001) Agir dans un monde incertain. Essai sur la démocratie technique. Paris: Seuil.

Chalvet, M. (2011) 'De la catastrophe à la prévention : une nouvelle sensibilité au risque incendie dans la presse régionale provençale des années 1960 aux années 1990' In Cousin, B. (ed.) Les sociétés méditerranéennes face au risque : représentations, pp. 159-172. Le Caire: Institut Français d'Archéologie Orientale. Charvolin, F. (2003) L'invention de l'environnement en France. Paris: La Découverte.

Claeys, C. (2010) (ed.) 'Iles et calanques de Marseille: discours, pratiques et attentes des marseillais'. Atelier méthodologique du Master MASS, promotions 2008-2010. Université de la Méditerranée.

Claeys, C. and O. Sirost (2010) 'Proliférantes natures. Introduction' Etudes Rurales, 185, Juin-Juillet: 9-22.

Claeys-Mekdade, C. (2003) Le lien politique à l'épreuve de l'environnement. Expériences camarguaises. Bruxelles : Peter Lang.

Claeys-Mekdade, C. and M. Jacqué (2000) 'Les fonctions " non-marchandes" d'une forêt méditerranéenne: loisir et détente sur le massif de la Clape'. Revue Forêt Méditerranéenne, T. XXI, no. 1: 19-24.

Claeys-Mekdade, C. and J. Sérandour (2009) 'Ce que le moustique nous apprend sur le dualisme anthropocentrisme/biocentrisme: perspective interdisciplinaire sociologie/biologie'. Natures, Sciences Sociétés, 17 (2): 136-144.

Claeys-Mekdade, C., G. Géniaux and S. Luchini (1999) 'Approche critique et mise en œuvre de la méthode d'évaluation contingente: Un dialogue entre économiste et sociologue'. Nature, Science et Sociétés, 7 (2): 35-47.

Corbin, A. (1995) (ed.) L'avènement des loisirs. Paris: Aubier.

Cordell, H. K., M. A. Tarrant and G. T. Gree (2003) 'Is the public viewpoint of wilderness shifting?'. International Journal of Wilderness, 9 (2): 27-32.

Crouzet, N., D. Pavon and H. Michaud (2009) 'Mise à jour de la liste des plantes vasculaires du département des Bouches-du-Rhône'. Bulletin de la Société Linnéenne de Provence, 60: 55-73.

Cutter, S. (1995) 'Race, class and environmental justice'. Progress in Human Geography, 19 (1): 107-118.

Deboudt, P. (2010) (ed.) Inégalités écologiques, territoires littoraux et développement durable. Villeneuve d'Asq: Septentrion Presses Universitaires. Drouin, J. M. (1991). L'écologie et son histoire, Réinventer la nature. Paris: Flammarion.

Dumas, P. J., L. Affre and T. Tatoni (2007). Structure, Dynamics and Vulnerability of Mediterranean Coastal Phryganas. The Buffon Legacy. National History in the 
21st Century. Dijon: Université de Bourgogne.

Dumazedier, J. (1974) Sociology of Leisure. Amsterdam: Elsevier.

Dunlap, R. E., K. Van Liere, A. Mertig and R. E. Jones (2000) 'Measuring endorsement of the New Ecological Paradigm: A Revised NEP Scale'. Journal of Social Issues, 56 (3): 425-442.

Eizner, N. (1994) (ed.) Les représentations sociales de l'environnement. Le cas de la France. Groupe de recherche sur les mutations des sociétés européennes, contrat MRT/CNRS, no. 501433.

Gendron, C., J. G. Vaillancourt, C. Claeys-Mekdade and A. Rajotte (2007) (eds.) Environnement et sciences sociales. Les défis de l'interdisciplinarité. Québec: PUL GipCalanques (2010) Etude de fréquentation terrestre et marine (available at www. gipcalanques.fr - consulted 10 May 2011)

Goiffon, M., J. N. Consalès (2005) 'Le massif des Calanques (Marseille-Cassis) et la Pointe des Châteaux (Saint-François, Guadeloupe). Périmètres d'intervention et mesures de protection sur deux grands sites littoraux périurbains'. Méditerranée Revue Géographique des Pays Méditerranéens, 3-4: 29-35.

Gontier, C. (1991) Le cabanon marseillais. Images et pratiques. Marseille: Cerfise. Gritti, E.S., B. Smith and M. T. Sykes (2006) 'Vulnerability of Mediterranean Basin ecosystems to climate change and invasion by exotic plant species'. Journal of Biogeography, 33 (1): 145-157.

Harmelin J. G., S. Sartoretto and P. Francour (1996). Patrimoine biologique marin de l'archipel de Riou: première évaluation. Rapport COM/Ville de Marseille, pp. 1-86. Direction de L'environnement et des Déchets.

Jetzkowitz, J. and S. Brunzel (2005) 'Transgressing the boundaries: An experimental reconnoitre'. Graduate Journal of Social Science, 2 (1): 134-147. Jollivet, M. (1992) Sciences de la nature/Sciences de l'homme. Les passeurs de frontières. Paris: CNRS.

Kalaora, B. (2001) 'A la conquête de la pleine nature'. Ethnologie Française, 4 (31): 591-597.

Larrère, C. (2009) 'La justice environnementale'. Multitudes, 1 (36): 156-162. Leriche, A., V. Pasqualini, C. F. Boudouresque, G. Bernard, P. Bonhomme, P. Clabaut and J. Denis (2006) 'Spatial, temporal and structural variations of a Posidonia oceanica seagrass meadow facing human activities'. Aquatic Botany, 84 (4) : 287-293.

Lévêque, C. (2001). Ecologie. De l'écosystème à la biosphère. Paris: Masson Sciences.

Marco, A., C. Barthelemy, T. Dutoit and V. Bertaudière-Montes (2010) 'Bridging human and natural sciences for a better understanding of urban floral patterns: The role of planting practices in Mediterranean gardens'. Ecology and Society, 15 (2): 2. (http://www.ecologyandsociety.org/vol15/iss2/art2/ - consulted 18 July 2011) Massena-Gourc, G. (1994) 'La protection à l'épreuve de la diversité des usages, le massif des Calanques'. Etudes Rurales, 133-134:149-162.

McKinney, M. L. (2002) 'Urbanization, biodiversity, and conservation'.

BioScience, 52 (10): 883-890.

Médail, F. and R. Verlaque (1997) 'Ecological characteristics and rarity of 
endemic plants from southeast France and Corsica: Implications for biodiversity conservation'. Biological Conservation, 80 (3): 269-281.

Munns, R. and M. Tester (2008) 'Mechanisms of salinity tolerance'. Annual Review of Plant Biology, 59: 651-681.

Ostrom, E. (2009) 'A general framework for analyzing sustainability of socialecological systems'. Science, 325 (5939): 419-422.

Pauchard, A., M. Aguayo, E. Peña and R. Urrutia (2006). 'Multiple effects of urbanization on the biodiversity of developing countries: The case of a fastgrowing metropolitan area (Concepciòn, Chile)'. Biological Conservation, 127 (3): 272-281.

Poilroux, H. (1982) Marseille et sa plaisance. Marseille: Maritimes et d'Outre-Mer. Roberts, K. (2006) Leisure in Contemporary Society. Wallingford: 2 CABI. Rosenzweig, M. (2003) Win-Win Ecology. How the Earth's Species Can Survive in the Midst of Human Enterprise. Oxford: Oxford University Press.

Rotondi, A., F. Rossi, C. Asunis and C. Cesaraccio (2003) 'Leaf xeromorphic adaptations of some plants of a coastal Mediterranean macchia ecosystem'. Journal of Mediterranean Ecology, 4 (3-4): 25-35.

Roux, D. J., R. J. Stirzaker, C. M. Breen, E. C. Lefroy and H. P. Cresswell (2010) 'Framework for participative reflection on the accomplishment of transdisciplinary research programs'. Environmental Science and Policy, 13 (8): 733-741.

Spaargaren, G. and A. P. J. Mol (1992) 'Sociology, environment, and modernity: Ecological modernization as a theory of social change', Society and Natural Resources, 5 (4): 323-344.

Swyngedouw, E. (2006) 'Impossible "Sustainability" and the Post-political Condition' In Gibbs, D. and R. Krueger (eds.), Sustainable Development, pp. 1340. New York, NY: Guilford Press.

Theys, J. (2007) 'Pourquoi les préoccupations sociales et environnementales s'ignorent-elles ? Un essai d'interprétation à partir du thème des inégalités écologiques' In Cornu, P., T. Bauler and E. Zaccaï (eds.) Environnement et inégalités sociales, pp. 23-35. Bruxelles : Université de Bruxelles. van den Born, R., R. H. J. Lenders, W. T. de Groot and E. Huijsman (2001) 'The new biophilia: an exploration of visions of nature in Western countries'. Environmental Conservation, 28 (1): 65-75. van Koppen, K. and W. T. Markham (2007) (eds.) Protecting Nature. Organizations and Networks in Europe and the USA. Cheltenham: Edwar Elgar. Wilks S. (2008) (ed.) Seeking Environmental Justice. Amsterdam: Rotopi. Wilson, E. O. (1993) 'Biophilia and the Conservation Ethic' In Kellert, S.R., E. O. Wilson (eds.) The Biophilia Hypothesis, pp. 32-41. Washington, DC: Island Press. 